\title{
The Offensive Depictions of Prophet Muhammad (SAW) in Western Media and its Consequences
}

\author{
Aijaz Ahmad Khan $\mid$ PhD Scholar \\ Mewar University, Rajasthan, India
}

\begin{abstract}
The controversies and provocations generated by the West and its media over depictions of Prophet Muhammad (SAW) are not only related to recent caricatures or cartoons but are also about the display of historical artwork. Recently, many Western organisations, newspapers, magazines, social networks and even websites organised seminars and events like the cartoon "Everybody Draw Mohammed Day!" to hurt and provoke the Muslim world. Muslims believe that visual depictions of all the Prophets should be prohibited and are particularly averse to visual representations of Prophet Muhammad $(S A W)$. The key concern is that the use of images can encourage idolatry. Islam does not allow the depictions of Prophet Muhammad (SAW); to do so goes against the faith of the Muslims and hurts their emotions. This article will focus on providing an analysis of the distorted images, fabricated views, and overgeneralizations which typically characterize Western representation of the Prophet (SAW) of Islam with reference to some particular incidents, chiefly the Charlie Hebdo controversy, Danish newspaper, controversial movie Innocence of Muslims, animated films and social networks. This analysis comprises of works by both Western and Muslim thinkers; it also includes biased and moderatel fair views depicted in the Western media.
\end{abstract}

Keywords: Portraits of Prophets $(A S)$, Drawings, Calligraphy, Media, Image Building

\section{Introduction}

The negative representation of Muslims and Prophet Mohammed (SAW) in Western media is not a recent fabrication. It has been operational and deeprooted in Western conceptualization ever since the first contacts with Islam and Muslims. Down to the Middle Ages, especially during the Crusades and along the Muslim expansion in Europe till the very days of the Third Millennium, the West has promoted almost the same stereotypes of the Prophet $(S A W)$ of Islam and Muslims. Throughout Western history, Islam and the Prophet $(S A W)$ of Islam have been negatively portrayed in books and church sermons by scholars, in paintings, litterateur, poetry, folklore and in political and religious discourse. The new spokesmen in all forms of media - print, radio, TV, video and the Internet are also replete with bias. They have reinvigorated Islamic discourse, developed a series of misconceptions and built up a huge anti-Islam audience throughout the world. Western media is rife with examples of insults to Islam and Prophet Mohammed $(S A W)$. It is fully affected by its historical baggage.

Depictions of Prophet Muhammad $(S A W)$ were rare, never numerous in any community or era throughout Islamic history, and appeared almost exclusively in the private medium of Persian and other miniature book illustrations. The key medium of public religious art in Islam was and is calligraphy. In Ottoman Turkey, the Hilya ${ }^{1}$ developed as a decorated visual arrangement of texts about Prophet Muhammad $(S A W)$ that was displayed as a portrait might be. 
The visual images and cartoons of Prophet Muhammad $(S A W)$ in the West and Western media were always infrequent but this changed in the 21 st century. In the Middle Ages, they were mostly hostile and most often appeared in illustrations of Dante's poetry. During the Renaissance and Early Modern Period, Prophet Muhammad $(S A W)$ was sometimes depicted, typically in a more neutral or heroic light. These depictions began to encounter protests from Muslims, and in the age of the Internet, a handful of caricature depictions printed in the European press caused global protests and controversy, and eventually led to violence.

There is disagreement about visual depictions of Prophet Muhammad ( $S A W)$. Only oral and written descriptions are readily accepted by all traditions of Islam. There are many Hadith which have explicitly prohibited Muslims from creating visual depictions of figures; only written physical descriptions are permitted whose authenticity is often accepted.

\section{Portraits of Prophet Muhammad $(S A W)$ in Western History}

Western representations of Prophet Muhammad $(S A W)$ were rare until the explosion of images following the invention of the printing press. He is shown in a few Medieval images, normally in an unflattering manner, often influenced by a brief mention in Dante's Divine Comedy. Prophet Muhammad $(S A W)$ sometimes figures in Western depictions of groups of influential people in world history. Such depictions tend to be favourable or neutral in intent; one example can be found at the United States Supreme Court building in Washington, D.C. Created in 1935, the frieze includes major historical lawgivers and places Prophet Muhammad $(S A W)$ alongside Hammurabi, Moses, Confucius, and others.

In 1955, a statue of Prophet Muhammad $(S A W)$ was removed from a courthouse in New York City after the ambassadors of Indonesia, Pakistan and Egypt requested its removal. The extremely rare representations of Prophet Muhammad $(S A W)$ in monumental sculpture are especially likely to be offensive to Muslims, as the statue is the classic form of idols, and fear of any hint of idolatry is the basis of Islamic prohibitions. Islamic art has almost always avoided sculptures on any subject.

The Prophet Muhammad $(S A W)$ is portrayed in a 15th-century fresco Last Judgement by Giovanni da Modena and the drawing, Dante's The Divine Comedy, ${ }^{2}$ in the Church of San Petronio, Bologna, Italy, and artwork by Salvador Dalí, Auguste Rodin, William Blake, and Gustave Doré. There are also numerous book illustrations showing Prophet Muhammad ( $S A W)$.

\section{Concept of Portraits in Major Religions of the World}

Some major religions have experienced times during their history when images of their religious figures were forbidden. In Judaism, one of the Ten Commandments forbids "graven images." In Byzantine Christianity during the periods of Iconoclasm in the 8th century and again during the 9th century, visual representations of sacred figures were forbidden. Even in the present day, different groups of Protestant Christians have had disputes about the 
appropriateness of having religious icons of Christ or the saints. The concern generally boils down to whether or not the image is becoming more important than what is being represented. ${ }^{3}$

Hindu religious books decline the depiction or images of God and other religious figures, "of him there is no likness (pratima), whose glory is infinite." In Islam, Hadith explicitly ban the drawing of images of any living creature. Hence, most Muslims avoid visual depictions of Prophet Muhammad (SAW) or any other prophet such as Prophet Abraham, Prophet Moses or Prophet Jesus (Peace be upon them). ${ }^{5}$

\section{Cartoons of Prophet Muhammad $(S A W)$ in Western Media and Muslim Responses}

Ridiculing and insulting the holiest figure in Islam is intolerable and unacceptable to Muslims. The abominable act of drawing hurtful cartoons of Prophet Muhammad ( $S A W)$ by Western media from time to time show wilful disrespect to Islam and Prophet Muhammad $(S A W)$ and has enraged Muslims across the world. For Muslims, portrayal of Prophet Muhammad $(S A W)$ is the vilest of sins and a serious religious offence. Prophet Muhammad $(S A W)$ and Islam have been negatively portrayed for petty benefits since decades. Now in the present times, the West and Western media have made it their profession to provoke the Muslims, and defame the religion of Truth and its Great Prophet $(S A W)$.

Der Spiegel, the German news magazine, printed a picture of "Moral Apostles" Prophet Muhammad $(S A W)$, Prophet Jesus $(S A W)$, Confucius, and Immanuel Kant. In the subsequent weeks, the magazine received protests, petitions and threats against publishing the picture of Prophet Muhammad $(S A W)$. The Turkish TV-station, Show TV, broadcast the telephone number of an editor who then received daily calls. ${ }^{6}$

In 2002, Italian police reported that they had disrupted a group of people out to destroy a church in Bologna, which contains a 15th-century fresco depicting an image of Prophet Muhammad $(S A W){ }^{7}$ In 2005, an episode of 30 Days with Morgan Spurlock, titled "Muslims and America," depicted Prophet Muhammad $(S A W)$ twice, in a cartoon explaining the origins of the Islamic faith. There was no outcry over this.

Prophet Muhammad ( $S A W$ ) appeared in the 2001 South Park episode "Super Best Friends". The image was later removed from the 2006 episode "Cartoon Wars" and the 2010 episodes "200" and "201" due to controversies regarding Prophet Muhammad ( $S A W)$ cartoons in the European newspaper.

In 2005, Danish newspaper Jyllands-Posten published a set of editorial cartoons, many of which depicted Prophet Muhammad ( $S A W)$. In late 2005 and early 2006, Danish Muslim organizations ignited a controversy through public protests and by spreading knowledge of the publication of the cartoons. According to John Woods, Islamic history professor at the University of Chicago, it was not simply the depiction of Prophet Muhammad $(S A W)$ that was offensive, but the 
implication that Prophet Muhammad $(S A W)$ was somehow a supporter of terrorism. In Sweden, an online caricature competition was announced in support of Jyllands-Posten, but Foreign Affairs Minister Laila Freivalds and the Swedish Security Service pressured the internet service provider to shut the page down. In 2006, when her involvement was revealed to the public, she had to resign.

On 12 February 2008, the Danish police arrested three men alleged to be involved in a plot to assassinate Kurt Westergaard, one of the cartoonists. ${ }^{8}$

In 2006, the controversial American animated television comedy program South Park, which had previously depicted Prophet Muhammad $(S A W)$ as a superhero character in the July 4, 2001 episode "Super Best Friends,"9 depicted Prophet Muhammad $(S A W)$ in the opening sequence since that episode attempted to satirize the Danish newspaper incident. In the episode, "Cartoon Wars Part II", they intended to show Prophet Muhammad $(S A W)$ handing a salmon helmet to Peter Griffin, a character from the Fox animated series Family Guy. However, Comedy Central, which airs South Park, rejected the scene, citing concerns of violent protests in the Islamic world. The creators of South Park reacted instead by satirizing Comedy Central's double standard for broadcast acceptability by including a segment of the episode "Cartoon Wars Part II" in which American President George W. Bush and Prophet Jesus $(A S)$ defecate on the flag of the United States.

The Lars Vilks Prophet Muhammad ( $S A W$ ) drawings controversy began in July 2007 with a series of drawings by Swedish artist Lars Vilks which depicted Prophet Muhammad $(S A W)$ as around about dog. Several art galleries in Sweden declined to show the drawings, citing security concerns and fear of violence. The controversy gained international attention after the Orebro-based regional newspaper Nerikes Allehanda published one of the drawings on August 18 to illustrate an editorial on self-censorship and freedom of religion.

While several other leading Swedish newspapers had already published the drawings, this particular publication led to protests from Muslims in Sweden as well as official condemnations from several foreign governments including Iran, Pakistan, Afghanistan, Egypt ${ }^{10}$ and Jordan ${ }^{11}$, as well as by the inter-governmental Organisation of the Islamic Conference (OIC) ${ }^{12}$. The controversy occurred about one and a half years after the Jyllands-Posten Prophet Muhammad $(S A W)$ cartoons controversy in Denmark in early 2006.

\section{List of Charlie Hebdo Provocative Publications}

The newspaper Charlie Hebdo published a series of satirical cartoons of Prophet Muhammad $(S A W)$ on the cover of November 3, 2011 edition, renamed Charia Hebdo (Sharia Hebdo). The word balloon reads "100 lashes if you don't die of laughter!" The cover of January 14, 2015 edition came with a cartoon in the same style as the November 3, 2011 cover, with the phrase Je Suis Charlie and the title reading "All is forgiven." ${ }^{13}$

On November 2, 2010, the office of the French satirical weekly newspaper Charlie Hebdo in Paris was attacked with a firebomb and its website hacked after 
it announced to publish a special edition with Prophet Muhammad (SAW) as its "chief editor", and the title page with a cartoon of Prophet Muhammad $(S A W)$ had been pre-issued on social media.

In September 2012, the newspaper published a series of satirical cartoons of Prophet Muhammad $(S A W)$, some of which featured nude caricatures of Him. In January 2013, Charlie Hebdo announced that they would make a comic book on the life of Prophet Muhammad $(S A W) .{ }^{14}$ In March 2013, Al-Qaeda's branch in Yemen, commonly known as Al-Qaeda in the Arabian Peninsula, released a hit list in an edition of their English-language magazine Inspire. The list included Stéphane Charbonnier, Lars Vilks, three Jyllands-Posten employees involved in the Prophet Muhammad's ( $S A W$ ) cartoon controversy, Molly Norris from the "Everybody Draw Mohammed Day" and others whom Al-Qaeda accused of insulting Islam. ${ }^{15}$

\section{a. Charlie Hebdo Attack}

The office of Charlie Hebdo was attacked again on January 7, 2015 and 12 people were shot dead including Stephane Charbonnier, the editor. The attack was widely reported and drew worldwide condemnation.

However, the attack itself and the reaction to it also exposed the divisions in French society as well as the hypocrisy of what is called the civilized world. Millions of people have been killed in the Muslim world; yet the world and Western media have maintained silence and this can only be described as double standards. On one hand, around 12 million people have been massacred in the Islamic world in the last 10 years, and on the other hand, 12 people were killed in Paris. We saw how world leaders and Western media representatives (who did not speak up about the killing of millions) stood up at a rally of two million people with scores of world leaders in the French capital to protest against the recent attacks in Paris against the murder of 12 people. Where were their lofty principles when 12 million Muslims were being massacred?

Charlie Hebdo isn't only about Islam. It is believed that the imaginary and insulting caricature of Prophet Muhammad $(S A W)$ is an insult and teasing satire on the faith of two billion Muslims and all those people who are peace lovers. Even Pope Francis admitted to this while on a visit to Catholic Philippine.

Many Muslims throughout the word condemned the Hebdo surgical killings. The death of a human is the death of humanity. Allah the Almighty says, "If any one slew a person - unless it be for murder or for spreading mischief in the land - it would be as if he slew the whole people: and if any one saved a life, it would be as if he saved the life of the whole people." ${ }^{16}$ Brutal killings, whether in Damascus, Baghdad, Afghanistan, Iraq, Gaza or in any other country, have no difference. If the world press and general populace do not react to all killings and massacres irrespective of religion or location, then all humanity will be doomed. 


\section{b. Attackers of Charlie Hebdo}

The cartoons of Prophet Muhammad $(S A W)$ on cover pages of Charlie Hebdo magazine were outrageous and provocative. This was intended to hurt the sentiments of Muslims across the world. The magazine has committed similar evil acts many times and by repeating the sinful act of blasphemy has hurt the religious sentiments of Muslims.

According to France 24 news channel, Charlie Hebdo attackers are reportedly of Algerian descent and third attacker is from Senegal. ${ }^{17}$ France invaded Algeria in the 1930s and began 130-year rule of murder, racism, loot and misrule costing over one million Algerian lives. Even in 1990, 100000 Algerian lives were lost with direct support from France and the West to preserve grip on power - Algeria is rich in petroleum and self elected puppets are supported to reign inside without being seen.

Nigeria, another major oil producer received similar support for its war against its own people in the 1960s causing one million deaths that later resulted in the emergence of Boko Haram. ${ }^{18}$ Most of the Muslim world except Iran, Turkey and the Arabian Peninsula fell to generations of misrule in the 19th and 20th centuries. People were looted, killed, exploited and then, when they were let free, colonised indirectly and invisibly. Now, colonialism is dressed in new clothes. International Monetary Fund and the World Bank have colonial policies that have brought about the bankruptcy of Muslim countries.

\section{c. Reaction of Attack in Paris}

France-based National Observatory Against Islamophobia reported, “At least 116 Islamophobic attacks on Muslims in France have been reported within two weeks of the Charlie Hebdo killings in Paris." Violence cannot be removed with violence and blood cannot be cleaned with blood. The world's security cannot be maintained by oppressing beliefs in the name of the War on Terror and by other provocative segments.

According to Abdullah Zekri, Head of the Observatory, attacks against Muslims in the country increased rapidly following the attack on the satirical magazine in Paris. In a statement, Zekri said that out of 116 attacks, 28 were onslaughts on Muslim prayer halls, while French security officials recorded 88 other threats and acts of intimidation against Muslims. ${ }^{19}$ Islamophobic attacks increased by 110 percent compared to the same period last year, Zekri added. He called for more effective methods to stop the attacks. "We expected effective measures for the protection of Muslims instead of speeches by the authorities," he said.

\section{d. Reaction of the Muslim World Media on Charlie Hebdo Attack}

The media in the Muslim world have also published a wide variety of reactions to the deadly attack on the offices of the satirical magazine Charlie Hebdo in Paris. In Iraq, the mainstream media paid very limited attention to the attack. Only three major Iraqi news outlets published news reports about the events. One 
newspaper also noted reactions from the Al-Azhar University in Cairo saying that Islam was against violence.

Paris-based Iraqi journalist Jawad Bishara told Radio Free Iraq's Samira Ali Mendi on January 082015 that the "Iraqi media have been largely indifferent because many more Iraqis are killed on a daily basis, and the outside world barely responds."

The Russian-language IslamNews.ru portal, which publishes news relating to Russian Muslims and the Muslim world, featured an opinion piece it solicited from Leonid Ivashov, the Kyrgyzstan-born Vice President of the Academy on Geopolitical Affairs. Ivashov blamed the United States for the attack, saying that the Charlie Hebdo shootings were "most likely planned in the United States to destroy Islamic culture, Islamic tradition, and to pit Europeans against Islam." Ivashov said that the world is witnessing a "clash of civilizations" and that the Muhammad cartoons published by Charlie Hebdo were an excuse to incite fanatics. The Daily Resalat said that the attack was a result of support for antiIslamic media and other groups.

Reactions to the shooting in the Arab world have been mixed, with some outlets condemning the attack and others suggesting that the French satirical magazine had brought the attack on itself. Other outlets blamed the West and "colonial policies" for the phenomenon of terrorism. Another common theme was whether the Islamic State Group was to blame for the attack. The Turkish press has widely reported about the Paris massacre. In commentaries, too, the overall voice was one of condemnation, despair, and sorrow. But the tone and intensity varied to some extent.

While many Afghan media were on their weekend holiday, the Afghan Taliban took the opportunity to publish an article on its website on January 82015 describing the killings as "an alarm bell for those who have in the past insulted Islam and the Prophet." The Taliban did not go so far as to openly support the attack. The article, written by one Ahmad Zarif, who is not an official spokesman for the Afghan Taliban, opined that, "Those who mocked the Prophet have strengthened their security."

The front pages of major Pakistani newspapers initially focused on straight news coverage, before commentaries and editorials began emerging.

Although the more independent and reformist-leaning newspapers such as Sharq and Etemad also carried the story on their front page, the space dedicated to the news was much less than that of the daily Iran or of Hamshahri, the official newspaper of Tehran's municipality.

Sharq's headline on the event, which was run at the bottom of its front page, read: "Shooting at the Heart of Europe." Sharq slammed the French satirical magazine for publishing Muhammad $(S A W)$ cartoons. "It is not acceptable that the president of France defends the freedom of speech in his speech after the attacks," wrote Sharq. "This popular journal had published an insulting illustration of the Prophet of Islam." 
Reformist Daily Etemad also headlined with Black Wednesday in Paris."Boosting the activities of extremist and anti-Islam groups and media (of which Charlie Hebdo was one) has led to the current security disaster in Europe," the outlet argued in an editorial. Resalat went on to say that "France has experienced the bitter taste of supporting terrorism."

The Newspaper Kayhan, which operates under the supervision of the office of the supreme leader, Ayatollah Ali Khamenei, was relatively mute in its coverage. Egypt's Shorouk News cast the blame for the attack on Charlie Hebdo itself. The paper's headline read that the French satirical magazine had a History of Insulting the Prophet, Ending in Fire.

Egyptian outlet Al Masry Al Youm reported comments by popular TV presenter Tamer Amin, who said that while some media reports have suggested that the IS group was behind the Paris shooting, "In my opinion, it was not IS that carried out this operation, but IS found an opportunity to say that it did in order to get a certain prestige." Amin said IS wanted to take advantage of the attack on Charlie Hebdo because the magazine had published caricatures of the Prophet Muhammad (SAW).

Egypt's Masr Alarabiya outlet pointed the finger of blame at IS, headlining with: IS Fulfils its Threat and Attacks France. Many other outlets criticized Charlie Hebdo for publishing cartoons mocking the Prophet Muhammad (SAW) and questioned whether such cartoons constituted free speech.

\section{Depictions of Prophet Muhammad $(S A W)$ in Cinema}

Muslims have always explicitly prohibited the depiction of Prophet Muhammad (Peace be upon Him). Depicting the Prophets is wrong and is haraam, and it is not permissible even if some Muslims do that in Films.

Very few films have been made about Prophet Muhammad (SAW). The 1976 film 'The Message', also known as Muhammad $(S A W)$, Messenger of God, focused on other persons and never directly showed Prophet Muhammad $(S A W)$ or most members of His family.

\section{a. The Message}

Muhammad $(S A W)$, Messenger of God, released in the US as 'The Message', was the first major film about Prophet Muhammad $(S A W)$. The film was released on January 1, 1976 and on July 29 of the same year it had its premiere in Plaza, a London cinema. There are two versions of the movie, an English one and an Arabic one. The Arab version had also its premiere in a London cinema, Curzon, on August 19, 1976. Both versions were screened till September 29. So the English version was shown for nine weeks, and the Arab version for six weeks.

When director Mustafa Akkad (1935-2005) was shooting the film, he made use of an American cast and an Egyptian cast. In the English version, Anthony Quinn played Hamza $(R A)$, Michael Ansara Prophet Muhammad's $(S A W)$ principal opponent Abu Sufyan, and Irene Papas Abu Sufyan's wife Hind. In the Arab version, these roles were played by Egyptian actors. However, in a number of 
overall shots, in which a large group is acting, such as the Battle of Badr, it can be heard that the scene is shot only once, as the actors shout "Allahu Akbar." whereas in other similar scenes the director opted for "God is great."

Although the movie is about Prophet Muhammad $(S A W)$, the director decided to shoot the film so as not to depict Prophet Muhammad ( $S A W)$. Akkad frequently changed the position of the camera at moments when Prophet Muhammad ( $S A W)$ would be brought into vision. When Prophet Muhammad $(S A W)$ was essential to a scene, the camera would show events from his point of view. ${ }^{20}$

The Message became very popular, not the least in the circles of Muslims, for example in Africa, and Asia. Even so, two well-known fatwas from Al-Azhar University and Shiite Council of Lebanon were issued about The Message.

It is certainly probable that this is not the result of the creativity of the filmmakers but of the rules announced by the Islamic scholars of the Azhar and the Shia Council of Lebanon, who prohibited any representation of Prophet Muhammad's $(S A W)$ wives as well as of Prophet Muhammad $(S A W)$ himself. ${ }^{21}$

\section{b. Muhammad $(S A W)$ : The Last Prophet}

Muhammad $(S A W)$ : The Last Prophet is an animated film produced by Badr International according to the same principles as "The Message". Its director is Richard Rich. The movie was released in 2004 and it was screened in a limited number of movie-theatres in the United States and the United Kingdom. The film focuses on the early period of Islam.

\section{c. Innocence of Muslims}

The anti-Muslim 14-minute video clip called The Real Life of Prophet Muhammad $(S A W)$ or 'Innocence of Muslims' is a story which was created by Nakoula Basseley Nakoula. It was uploaded onto YouTube in July 2012 and later dubbed in Arabic and uploaded in September 2012. It was perceived as denigrating of Prophet Muhammad $(S A W)$, and caused demonstrations and violent protests against the video to break out on September 11 in Egypt and other Arab and Muslim nations, as well as some western countries. ${ }^{22}$

\section{Depictions of Other Prophets (AS) and Sahaabah/Companions $(R A)$ in Cinemas}

It is not permissible to depict the Prophets and Messengers of Allah (Blessings and Peace of Allah be upon them) or to depict the Sahaabah (May Allah be pleased with them), because doing that involves detracting from their status and showing disrespect to them. It is also a transgression against their dignity and undermines them because it involves fabrications and lies against the best of the creation of Allah the Almighty.

\section{a. The Messiah}

This was a film on Prophet Jesus $(A S)$, its producer claimed that he made this movie from an Islamic point of view, as his idea was based on denying the story of the crucifixion, in accordance with what is mentioned in the Holy Qur'an, ${ }^{23}$ 
"That they rejected Faith; That they uttered against Mary A grave false charge; That they said (in boast): 'We killed Christ Jesus The son of Mary, The Messenger of Allah.' But they killed him not, Nor crucified him, but so it was made to appear to them, and those who differ therein are full of doubts, with no (certain) knowledge, but only conjunction to follow, for of a surety they killed him not. Nay, Allah raised him up Unto Himself; and Allah Is Exalted in Power, Wise. And there is none of the people of the book (Jews and Christians) But must believe in him (Jesus) before his death; And on the Day of Judgment He (Jesus) will be a witness against them."

He also affirmed that the Messiah foretold the coming of our Prophet Muhammad $(S A W)$. He said that it was primarily aimed at the West to refute the repeated Western insults of our Prophet $(S A W)$ in particular and of Islam in general; to highlight the status of the Messiah ( $S A W)$ among the Muslims; to show that Islam teaches belief in all the Prophets and Messengers of Allah without exception, and that it does not discriminate between them.

We believe that the Messiah (AS) was not crucified and killed, and the Holy Qur'an clearly states that we do not agree that this should be presented in theatrical or cinematic form in which a person acts the part of the Messiah $(A S)$, or even that a picture should be drawn of him. All that is forbidden and is haraam, because it detracts from the status of the Prophets of Allah $(S A W)$ and lowers their status in people's eyes, because it usually involves telling some kind of lies about them and shows them in a manner other than how they really were, whether that is to a lesser or greater extent. So, it is not permissible for anyone to tell lies about the Prophets of Allah $(A S)$ or to detract from their status, or to depict them, no matter how noble his intention or aim is. The intention may be noble but the means must also be Islamically acceptable.

In that case, a mistake made by some Muslims should not be taken as proof against sharee 'ah; nor is it a mistake for which all Muslims should be blamed. Allah, may He be exalted, says, "Say: Shall I seek a lord other than Allah, while $\mathrm{He}$ is the Lord of all things? No person earns any (sin) except against himself (only), and no bearer of burdens shall bear the burden of another. Then unto your Lord is your return, so He will tell you that wherein you have been differing."24

\section{b. Other Film Projects}

In October 2008, Producer Oscar Zoghbi, who worked on the original "The Message", stated that he would be shooting a remake called The Messenger of Peace, to be shot around the holy cities of Mecca and Medina. ${ }^{25}$

In October 2012, Iranian director Majid Majidi began shooting a film titled Muhammad $(S A W)$ with plans to show Prophet Muhammad $(S A W)$ on screen, though not his face, as per Shia tradition.

Film producer Barrie M. Osborne has been hired as an adviser on a possible series of epics about Prophet Muhammad $(S A W)$. The films, which are financed by a Qatari media company and will be supervised by the Egyptian cleric Yusuf 
al-Qaradawi, are unlikely to depict Prophet Muhammad (SAW) at all on screen as per Sunni tradition which sees all renderings of the Prophet as blasphemous. ${ }^{26}$

\section{Calligraphy: Prophet Muhammad $(S A W)$ in Islamic Art}

Calligraphy is a continuous tradition in Islamic lands (such as in literature, science, and history). As early as the 8th century, such art flourished during the Abbasid Caliphate (c. 749 - 1258, across Spain, North Africa, Egypt, Syria, Turkey, Mesopotamia, and Persia). ${ }^{27}$

The elaborated form of the calligraphic tradition was founded in the 17th century by the Ottoman calligrapher Hafiz Osman. ${ }^{28}$ The format customarily starts with a Bismillah, shown on top, and is separated in the middle by the Holy Quran 21:107: "And We have not sent you (Muhammad $S A W$ ) but as a mercy to the worlds." ${ }^{29}$ Four compartments set around the central one often contain the names of the Rightly-Guided Caliphs, Abu Bakr, Umar, Uthman, and Ali, each followed by "radhi Allahu anhu" ("May Allah be pleased with them"). Depictions of Prophet Muhammad $(S A W)$ are also found in Persian manuscripts in the Timurid and Safavid dynasties, Turkish Ottoman Art in the 14th - 17th centuries, and beyond. Perhaps the most elaborate cycle of illustrations of Prophet Muhammad's $(S A W)$ life is the copy, completed in 1595, of the 14th-century biography Siyer- $i$ Nebi commissioned by the Ottoman Sultan Murat III for his son, the future Mehmed III, containing over 800 illustrations. ${ }^{30}$

Throughout Islamic history, depictions of Prophet Muhammad $(S A W)$ in Islamic art were rare. Even so, there exists a "notable corpus of images of Prophet Muhammad $(S A W)$ produced, mostly in the form of manuscript illustrations, in various regions of the Islamic world from the thirteenth century through modern times." ${ }^{31}$ Depictions of Prophet Muhammad $(S A W)$ date back to the start of the tradition of Persian miniatures as illustrations in books. The illustrated book from the Persianate world ${ }^{32}$ contains the two earliest known Islamic depictions of Prophet Muhammad $(S A W){ }^{33}$

"Islam has never welcomed painting as a handmaid of religion as both Buddhism and Christianity have done. Mosques have never been decorated with religious pictures, nor has a pictorial art been employed for the instruction of the heathen or for the edification of the faithful." 34

\section{Portraiture of Prophet Muhammad $(S A W)$ in Islamic Stories}

A number of Hadith and other writings of the early Islamic period include stories in which portraits of Prophet Muhammad $(S A W)$ appear. Abu Hanifa Dinawari, Ibn al-Faqih, Ibn Wahshiyya and Abu Nu'aym tell versions of a story in which the Byzantine Emperor Heraclius is visited by two Meccans. He shows them a cabinet, handed down to him from Alexander and originally created by Allah for Adam, each of whose drawers contains a portrait of a Prophet $(A S)$. They are astonished to see a portrait of Prophet Muhammad $(S A W)$ in the final drawer. Sadid al-Din al-Kazaruni tells a similar story in which the Meccans are visiting the king of China. Kisa'i tells that God did indeed give portraits of the prophets to Adam. ${ }^{35}$ 
Ibn Wahshiyya and Abu Nu'ayn tell a second story in which a Meccan merchant visiting Syria is invited to a Christian monastery where a number of sculptures and paintings depict prophets and saints. There he sees the images of Prophet Muhammad $(S A W)$ and Abu Bakr $(R A)$, as yet unidentified by the Christians. ${ }^{36}$ Later, Al-Maqrizi tells a story in which Muqawqis, ruler of Egypt, meets with Prophet Muhammad's ( $S A W$ ) envoy. He asks the envoy to describe Prophet Muhammad $(S A W)$ and checks the description against a portrait of an unknown prophet which he has on a piece of cloth. The description matches the portrait. ${ }^{37}$

In a 17th-century Chinese story, the king of China asks to see Prophet Muhammad $(S A W)$, but Prophet Muhammad $(S A W)$ instead sends his portrait. The king is so enamoured of the portrait that he is converted to Islam, at which point the portrait, having done its job, disappears. ${ }^{38}$

\section{The Personality of Prophet Muhammad $(\mathrm{SAW})$ as Depicted by His Companions $(R A)$}

Al-Quran"(O Beloved!) We have been watching your radiant face turning frequently towards heaven. So We will indeed make you turn towards that Qibla (direction of Prayer) with which you feel pleased...... ${ }^{39 "}$

Starting with the verse of Quran where Allah told us about the importance he had for Prophet Muhammad's $(S A W)$ face Allah saw it turning toward heavens so he changed the Qibla because of that face.

Transmitted from Ali [son-in-law of the Prophet], may Allah be pleased with him, who, when asked to describe the Prophet $(S A W)$, would say,

He was not too tall nor too short. He was medium sized. His hair was not short and curly, nor was it lank but in between. His face was not narrow, nor was it fully round, but there was a roundness to it. His skin was white. His eyes were black. He had long eyelashes. He was big-boned and had wide shoulders. He had no body hair except in the middle of his chest. He had thick hands and feet. When he walked, he walked inclined, as if descending a slope. When he looked at someone, he looked at them in full face. "Between his shoulders was the seal of prophecy, the sign that he was the last of the prophets. He was the most generous-hearted of men, the most truthful of them in speech, the most mildtempered of them, and the noblest of them in lineage. Whoever saw him unexpectedly was in awe of him. And whoever associated with him familiarly loved him. Anyone who would describe him would say, 'I never saw, before him or after him, the like of him.' Peace be upon him.

Al-Hasan, son of Ali [May Allah be pleased with both of them] said, "I asked my uncle, Hind, son of Abu Hala about the hilye [description] of the Prophet of Allah, may peace and blessings be upon him. Hind was known to be a prolific describer of the Prophet, and I wished him to relate some of it for me so I might hold fast to it." So Hind said,

The Prophet of Allah, peace be upon him, was of mighty significance to Allah and profoundly honored among the people. His face radiated light like the moon on its fullest night. He was a bit taller than the medium stature and a bit shorter than the tall and skinny. His head was large. His hair was wavy. If his hair 
parted, he would leave it parted; if not, he would leave it, and it would not be long enough to pass his earlobes. His complexion was fair. He had a wide forehead and arched, thick eye brows with a space between them. There was a vein between them that would swell and pulse when he was angry. His nose was aquiline; it had a brightness about the upper part that led those who were less observant to think him haughty. He had a thick beard. His eyes were very black and the whites very white. His cheeks were not prominent. He had a wide mouth. His teeth were white, and there was a space between his front teeth. "There was a fine line of hair on his chest, and it was as if it were an ivory statue with the purity of silver. His figure was well proportioned, full-bodied, and strong. There was no slackness in his musculature; his chest didn't protrude over his belly, nor did the reverse occur. His chest was broad and his shoulders wide and muscular. He had large limbs. The parts of his body that could be seen while he was clothed were luminous. His body from the neck to the navel was joined by hair which flowed down like a line. There was no hair on his nipples. His forearms, shoulders, and upper chest were hairy. The bones of his forearms were long. His palms were wide and generous. His hands and feet were thick. His limbs were long. He had long sinews. His insteps were high. His feet were smooth without protuberances, and water would run off of them. When he would move off, he would move with determination. He would step surely and unhurriedly and not proudly. He walked gently and with dignity, and he would take wide steps when he wanted to walk quickly. When he walked, it was as if he were descending from a slope, and when he would look at someone, he would turn to him fully. He would lower his gaze and look down more often than up. He didn't stare. He would lead his companions by walking behind them out of modesty and would always be the first to greet them.

At this point, Al-Hasan said to Hind, "Describe to me the way he spoke." Hind said,

The Prophet of Allah, peace and blessings be upon him, was continually full of concern. He was constantly deep in thought. He had no rest and would not speak without a reason. He would be silent for long periods of time. He would begin conversations and end them clearly and distinctly and would speak in a way that combined many meanings in few words. He spoke with excellence, and there was no excess in it or unnatural brevity. He was gentle by nature and not coarse, and he was not contemptuous of anyone. He would extol the favors he received even when they were few and small. He never found fault with them. He never criticized the food or drink that was prepared for him, nor did he overly praise it. No one would stand against his anger when matters of the Lord's truth were opposed until he had triumphed, but he would never get angry for his own sake, nor would he ever seek to win such an argument. He would gesture with his whole palm, to point. When astonished, he would turn the face of his palm upwards. He used his hands frequently as he spoke and would strike his left palm with his right thumb. When he would get angry, he would turn away and avert his gaze, and when he was full of joy, he would lower his eyes. Most of his laughing was as smiling; when he did laugh, it was not loud, and he would show his teeth a bit like they were hailstones.

Islam renounces the practice of violence, whether they are Muslim or anything else. Allah the Almighty Says "if any one slew a person..... It would be as if he slew the whole people: and if any one saved a life, it would be as if he saved the 
life of the whole people" ${ }^{\prime 4}$. But instead of this western Media is lying and spreading hate very tactfully about Islam and Prophet $(S A W)$ of Islam. Allah Almighty spoke in another Noble Verse of the Glorious Quran about the liars and deceivers, and promised them Hell Fire for their evil:"And, do not cloak (and confuse) the truth with falsehood. Do not suppress the truth knowingly. "41 the punishment of these wicked will be Hell as Allah says, "And verily, the Fujjar (the wicked, sinners, evil-doers....) will be in the blazing Fire (Hell)." ${ }^{42}$

So we should follow that straight path, the path of those with whom Allah Almighty is pleased of the Prophets (AS), Siddeeqs, Martyrs and Righteous, and we should refrain from that which is closer to frivolity and fulfilling whims and desires than it is to serious effort and high resolve. 


\section{References and Endnotes}

1 The term Hilya denotes a religious genre of Ottoman Turkish literature, dealing with the physical description of Prophet Muhammad $(S A W)$. Hilya literally means "ornament".

2 Jonathan E. Brockopp, The Cambridge companion to Muhammad (Cambridge University Press, 2010),130.

3 Richard Halicks, "Images of Muhammad: Three Ways to See a Cartoon," in Atlanta Journal-Constitution., (2006-02-12).

4 Shuklayajur Veda 32.3

5 T. W. Arnold, "An Indian Picture of Muhammad and His Companions," in The Burlington Magazine for Connoisseurs, Vol. 34, No. 195(June 1919): 249-252. Retrieved 2007-05-01.

6 Spiegel Special, p1, age 76. Spiegel, Terror amTelefon, February 7, 2000.

7 "Italy frees Fresco Suspects,"New York Times, 2002-08-22. http://www.nytimes.com/2002/08/22/world/italy-frees-fresco-suspects.html

8 Danish cartoons 'plotters' held BBC, 12 February 2008 http://news.bbc.co.uk/player/nol/newsid_7240000/newsid_7241300/7241394.stm

9 South Park.Season 5"Super Best Friends" Episode 68. 2001-07-04.

10 Gwladys Fouché, "Egypt wades into Swedish cartoons Row," The Guardian, 200709-09. http://www.theguardian.com/media/2007/sep/03/pressandpublishing2

11 Agence France-Presse, "Jordan condemns new Swedish Mohammed Cartoon," 2007-09-03. http://www.theguardian.com/media/2007/sep/03/pressandpublishing2

12 Organisation of the Islamic Conference." The Secretary General strongly condemned the publishing of blasphemous caricatures of Prophet Muhammad $(S A W)$ by Swedish artist" (Press release). 2007-08-30

13 "How I created the Charlie Hebdo magazine cover: cartoonist Luz's statement in full". The Telegraph. 13 Jan 2015.

http://www.telegraph.co.uk/news/worldnews/europe/france/11343077/How-Icreated-the-Charlie-Hebdo-magazine-cover-cartoonist-Luzs-statement-in-full.html

14 Jerome Taylor, "It's Charlie Hebdo's right to draw Muhammad, but they missed the opportunity to do something profound" The Independent. 12 October 2014. http://www.independent.co.uk/voices/comment/its-charlie-hebdos-right-to-drawmuhammad-but-they-missed-the-opportunity-to-do-something-profound8435693.html

15 Michael Burleigh "ANALYSIS: Was Charlie Hebdo massacre Al-Qaeda's bid to reestablish itself as global terror force after being 'eclipsed by ISIS", The Independent. 9 January 2015. http://www.dailymail.co.uk/news/article-2901892/ANALYSISCharlie-Hebdo-massacre-Al-Qaeda-s-bid-establish-global-terror-force-eclipsed-ISISasks-Michael-Burleigh.html

16 Al-Maida 05: 32.

17 Anthony Ham, Lonely Planet West Africa. (2009), 670

18 Al Jazeera "Civilians among dead in Nigeria offensive" 31 May 2013. http://www.aljazeera.com/news/africa/2013/05/2013531142139248993.html

19 France has one of the largest percentages of Muslims living in Western Europe, around eight million in total.

20 Oleg Grabar, "The Story of Portraits of the Prophet Muhammad," Studia Islamica no. 96, Écriture, Calligraphie et Peinture (2003):27.

21 Ibid.,43 
22 Brendan. The Arab Conquests of the Middle East (USA: Twenty First Century

Books, 2009), 34.

23 An-Nisa 04:156-159.

24 Al-An'aam 06: 164.

25 Christiane Gruber, "Images of the Prophet In and Out of Modernity: The Curious Case of a 2008 Mural in Tehran," in Christiane Gruber and Sune Haugbolle (eds.), Visual Culture in the Modern Middle East: Rhetoric of the Image (Indiana University Press, 2013), 3-31.

26 Omid Safi, Memories of Muhammad (Peace be upon Him): Why the Prophet Matters (Harper Collins, 2010),171; Thomas W. Arnold, Painting in Islam, a Study of the Place of Pictorial Art in Muslim Culture.[Gorgias Press LLC, (First published 1928, reprint 2002-11], 91-9.

27 J. Bloom \& S. Blair, Grove Encyclopaedia of Islamic Art (New York: Oxford University Press, Inc., 2009), 192, 207.

28 F. E. Peters, Jesus and Muhammad (Peace be upon Him): Parallel Tracks, Parallel Lives (Oxford University Press,2011), 160-161.

29 Jonathan E. Brockopp, The Cambridge Companion to Muhammad, 130.

30 Tanındı, Zeren, Siyer-i nebî: İslam tasvirsanatında Hz. Muhammed inhayatı. HürriyetVakfıYayınları, 1984).

31 Christiane Gruber, "Representations of the Prophet Muhammad in Islamic Painting," in Gulru Necipoglu, Karen Leal eds., Muqarnas Volume 26 (2009): 240-241.

32 Warka and Gulshah, Topkapi Palace Library 841, attributed to Konya 1200-1250

33 Grabar, "The Story of Portraits of the Prophet Muhammad", 19; Christiane Gruber, Representations of the Prophet Muhammad in Islamic painting, 235.

34 Thomas W. Arnold, Painting in Islam, a Study of the Place of Pictorial Art in Muslim Culture [Gorgias Press LLC, (First published 1928, reprint 2002-11], 91-9.

35 Oleg Grabar, "The Story of Portraits of the Prophet Muhammad (Peace be upon Him)," Studia Islamica (96): 19-38.

36 Ali Asani, Celebrating Muhammad (Peace be upon Him): Images of the Prophet in Popular Muslim Piety (University of South Carolina Press, 1995), 64-65.

37 Oleg Grabar, "The Story of Portraits of the Prophet Muhammad (Peace be upon Him)," 19-38.

38 Donald Leslie, Islam in Traditional China (Canberra College of Advanced Education, 1986), 73.

39 Al-Baqara 02:144

40 al-Maeda 05:32

41 al-Baqara 02:42

42 al-Infitar 82:14 


\section{Selected Bibliography}

1. Arnold, T. W. "An Indian Picture of Muhammad (Peace be upon Him) and His Companions (RA)." The Burlington Magazine for Connoisseurs. (June 1919).

2. January, Brendan. The Arab Conquests of the Middle East. USA: Twenty First Century Books, 2009.

3. Safi, Omid. Memories of Muhammad (Peace be upon Him): Why the Prophet Matters. 2 November 2010.

4. Abu-Lughod, Lila. Do Muslim Women Need Saving? Harvard University Press, 2013.

5. Abu-Lughod, Lila. Dramas of Nationhood: The Politics of Television in Egypt, University of Chicago Press, 2005.

6. Thompson, Elizabeth F. Justice Interrupted: The Struggle for Constitutional Government in the Middle East. Harvard University Press, 2013.

7. Gruber, Christiane, "Images of the Prophet In and Out of Modernity: The Curious Case of a 2008 Mural in Tehran.” In Christiane Gruber; Sune Haugbolle, (eds.), Visual Culture in the Modern Middle East: Rhetoric of the Image. Indiana University Press, 2013.

8. Arnold, Thomas W. Painting in Islam, a Study of the Place of Pictorial Art in Muslim Culture. Gorgias Press LLC (First published 1928, reprint 2002-11).

9. Ernst, Carl W. Following Muhammad: Rethinking Islam in the Contemporary World. UNC Press Books. 2004.

10. Eaton, Charles Le Gai. Islam and the Destiny of Man. State University of New York Press. 1985.

11. Halicks. Richard. "Images of Muhammad: Three ways to See a Cartoon." Atlanta JournalConstitution. 2006.

12. Asani, Ali. Celebrating Muhammad: Images of the Prophet in Popular Muslim Piety. Columbia, SC: University of South Carolina Press. 1995.

13. Hussain, M. "Islam, Media, and Minorities in Denmark." Current Sociology, vol 48, 04 (2000):95-116.

14. Ibrahim, D. "The Framing of Islam on Network News Following the September $11^{\text {th }}$ Attacks". International Communication Gazette.

15. Leslie, Donald. Islam in Traditional China. Sankt Augustin, Germany: Monumenta Serica Monograph, 2006.

16. Ibn Sa'd - Kitabh al-Tabaqat al-Kabir, as translated by S. Moinul and H.K. Ghazanfar, Kitab Bhavan, New Delhi.

17. Burke, Jason, Al-Qaeda: Casting a Shadow of Terror. I. B. Tauris, 2003.

18. Peters. F. E. Jesus and Muhammad: Parallel Tracks, Parallel Lives. Oxford University Press, 2010.

19. Brockopp, Jonathan E. The Cambridge Companion to Muhammad (Peace be upon Him). Cambridge University Press, 2010.

20. Blair, Sheila S. "The Development of the Illustrated Book in Iran”. Muqarnas Vol. 10, Essays in Honor of Oleg Grabar (1993): 266-274

21. Bloom J. \& S. Blair. Grove Encyclopaedia of Islamic Art. New York: Oxford University Press. 2009.

22. Gruber, Christiane. The Ilkhanid Book of Ascension. Tauris Academic Studies. 2010.

23. Ramadan, T. Good Muslim, Bad Muslim. New Statesman, 2010.

24. Ratnesar, Romesh. "Ground Zero: Exaggerating the Jihadist Threat." Time (August 18).

25. Schimmel, Annemarie. Deciphering the Signs of God: a Phenomenological Approach to Islam. SUNY Press, 1994.

26. Nawar, Ibrahim. Media Freedom and Dialogue. Arab Press Freedom Watch, February 2006. 